\title{
Developing Android Role Playing Game for Elementary Music Learning
}

\author{
${ }^{\otimes}$. Gita Ardhy Nugraha ${ }^{1}$, Totok Sumaryanto ${ }^{2}$, Kamsijo Budi Utomo $^{2}$ \\ ${ }^{1}$ Bethany Elementary School, Indonesia \\ ${ }^{2}$ Faculty of Language and Art, Universitas Negeri Semarang, Indonesia \\ Received: April 10, 2018. Revised: October 7, 2018. Accepted: December 24, 2018
}

\begin{abstract}
Elementary students prefer to listen to modern songs from the device that they have in their daily life. In the music learning process, the student feels bored because of the monotone learning method, even though the music art learning process is an important process to promote student knowledge about Indonesia's traditional songs. Innovation is needed because of this condition. This study aims to design and develop an android role-playing game (RPG) for music learning, especially Indonesia's traditional songs. This study also analyses the worthiness of android RPG game based on expert judgment validation's score. Based on expert judgment validation's score, the music art learning media called "Lagu Nusantara" is worthy of supporting the student to learn about the basic of music learning and Indonesia's traditional songs. The average score is 3.6 for media representation, 4 for the material which presented in this game, and 3.3 for the use of language. The worthiness of this media is above $90 \%$ (precisely $90.83 \%$ ). In conclusion, this RPG game can use by teachers or students to promote music art learning process, especially about Indonesia's traditional songs.
\end{abstract}

Keywords: Role-Playing Game; Android, Music Art; Indonesia's Traditional Song

How to Cite: Nugraha, R. G. A., Sumaryanto, T., \& Utomo, K. B. (2018). Developing Android Role Playing Game for Elementary Music Learning. Harmonia: Journal of Arts Research And Education, 18(2), 197-207.

\section{INTRODUCTION}

Music learning process in elementary school aims to make and develop student's character. In the music learning process, the teacher can give moral and cultural value through songs that have provided by the teacher. The existence of music learning in the elementary school allows the teacher to develop student's behavior, attitude, and character since the early stage (Mulyono, 2012). Furthermore, an aesthetic sense that trained through music learning is expected to build and develop a student's personality in a better way (Wicaksono, 2009).
Music learning in elementary school is an important process to tell and remind the student about Indonesia's traditional songs wealth. Furthermore, Indonesia's traditional songs reflect people's character who lived in the origin of traditional song (Suharto et al., 2017; Alfianto et al., 2014). Indonesia's traditional songs have deep moral value and can be learned through the learning process (Indrawan et al., 2016). Some of Indonesia's traditional songs also have spiritual significance as thanks to God (Wijayanto et al., 2015; Septiana et al., 2016).

Based on interview and observa-

\footnotetext{
${ }^{\square}$ Corresponding author: Jl. Kalipengging No. 4a, Salatiga, Indonesia

E-mail: nug.ardhy@students.unnes.ac.id
} 
tion in the music learning process, we found that the aim of music learning was not delivered well to the student. We saw some students were not paying attention to the material that given by their teacher. Students felt bored because a lot of music learning process was delivered by theoretical and directly practice with a musical instrument, not playing songs directly (Kusumadewi et al., 2011). They also more memorized pop or western songs than Indonesia's traditional songs (Nadir, 2016). Indonesia's traditional songs become evicted because of foreign cultural influx which affects the way of playing music and singing a song in Indonesia's society (Sumirat, 2014). Moreover, the lack of introduction of Indonesia's traditional songs to children since early stage causing less interest of the child to know and learn their traditional songs (Alam et al., 2014).

Based on observation, the music learning process in the elementary school perceived less utilize technology device that exists in the class. The teacher will use it if needed. Music learning is focusing on theory and practice wherein theory be basic to do further practical method (Amriyeni, 2013). The teacher admitted that the use of technological devices for music learning rarely used. The teacher realized that the lack of utilization of technological tools in the learning process makes students less interested in the learning activity.

Today elementary student generation are children who grow in the rapid development of technology. They were accustomed to playing games on their computer, gadget, and other technological devices (Furió, 2015). If it used well in the learning process, the use of technological devices not only encourage motivation but also improves student's positive behaviors (Ciampa, 2014). No findings suggest that using technological devices provides adverse outcomes for the learning process (Haßler et al., 2016).

The using of technological devices especially mobile devices for music learning process is an alternative method to address the rapid development of techno- logy. The teacher explained that use mobile devices for music learning process are needed if viewed from student's habit who often use mobile devices. Use a mobile device in the music learning process is an innovation that can help students to learn and improve student's sense of music (Rahmawan, 2016). The teacher also explained that music learning which packed by mobile games especially RPG games could affect student's interest and motivation in the learning process because it is familiar for them like Mobile Legends game. RPG or Role-Playing Game is one of games genre which has a storyline and main actor which played by the user (Syaifudin, 2016). Inside this game, some actors cannot play by the user. It is called Non-Player Characters (NPC). NPC in this game helps the lead actor to finish storyline because they are connected to each other (Perez, 2016, p. XXIV). This game also has a connection with each level and story so that students feel challenged to finish the story (Maharani, 2016).

Through interview and observation, we found that learning media which packed in mobile games is needed to answer the challenges of information technology, especially in the music learning process. From the previous research, Ciampa (2014) found that student could work cooperatively with their friends through mobile learning and increased positive behaviors. The using of mobile devices in the learning process also gives positive outcomes for students (Fokides et al., 2016). Makes music learning fun (Wagner, 2017), engage student's competences in basic music theory (Chung et al., 2017), and increase student's ability to read music score (Ng et al., 2015) are the advantages of mobile game learning. RPG games in the learning process also worthy to use as learning media (Hikam et al., 2013; Sari et al., 2014; Asriyatun et al., 2014; Maharani et al., 2016; Ningsih et al., 2016).

Music art is a kind of art that accepted by the human sense of hearing (Bahari, 2008, p. 55). In education process, music art gives experiences for students and to 
help individual development that can impact on the growth of student's mind, social, and emotion (Desyandri, 2008, p. 61). Music art also is a tool that helps students to get better personality and character (Mulyono, 2012). Music art can be delivered by digital media, especially mobile games. If it applied well, digital media gives a lot of advantages (Daryanto, 2013) such as (1) makes message in the learning process clearly, (2) become a solution to overcome the limitations of space, time, energy, and sensory energy owned by teachers or students, (3) increase students interest and motivation, (4) allow students to learn independently.

This study aims to design and develop android RPG game for music learning, especially Indonesia's traditional song. This study also analyses the worthiness of android RPG game based on expert judgment validation's score. This game built with RPG Maker MV software which developed by Kadokawa Games.

\section{METHOD}

This study uses research and development method which is used to create and test the effectiveness of the product (Sugiyono, 2015, p. 407). We used R \& D model which design by Branch (2009) with ADDIE (Analyze, Design, Develop, Implement, Evaluate) steps. We develop android RPG games based on "Permendikbud No. 24 Tahun 2016" especially for Indonesia's traditional songs in the elementary music art learning. We use RPG Maker MV version 1.5.1 to build this game. Our research data obtained from the validation test of material, media, and language. Because of our limitation, we used a simple step of ADDIE method and eliminate the "implement" step.

\section{RESULT AND DISCUSSION}

\section{Music Art Learning Through Mobile Games is Needed}

Student knowledge of Indonesia's traditional songs was lacked. They prefer to listen to modern songs than traditional songs (Nadir, 2016). Although there is internet access in their school or home, they used the internet for entertaining their self like playing games or watching online video (Su \& Cheng, 2015). The lack of student's knowledge about Indonesia's traditional song also caused by parent habits. For example, parents are often listening to the modern song, and their children learn a song which heard by their parents (Alam et al., 2014). Because of this condition, the teacher wants to teach their students about Indonesia's traditional song in music art learning.

The teacher knows that teaching Indonesia's traditional songs for elementary students is urgently needed. It will develop student's character from the moral value that conceived by each song (Alfianto et al., 2014; Rosmiati, 2014; Indrawan et al., 2016; Sukoyo, 2017). It also helps students to know and learn Indonesia's culture (Raharja et al., 2014; Irawan et al., 2014; Yudarta \& Pasek, 2017). The teacher also realized that teaching Indonesia's traditional song is an essential thing. Because of that, the teacher makes every effort to explain it to students through learning innovation. The learning innovation that the teacher did is about the use of the technological device in the learning process. But, the teacher taught that was not enough to increase student's interest and motivation for learning Indonesia's traditional songs. Students seem bored while the teacher explained Indonesia's traditional song directly. The teacher needs something new to teach it to the student.

Based on student experiences about mobile devices, the teacher assumed that mobile devices could help the student to learn Indonesia's traditional songs. The teacher explained that the use of mobile devices in the learning process has a positive and negative effect. But, the teacher trusted that mobile devices could help student well in the music learning process, agreed with Wagner (2017) and Chung, (2017) explanations. In addition, adding games in the learning process through mo- 
bile devices is a better way to tell students about Indonesia's traditional songs. The student will be challenging because they can learn while playing a mobile game ( $\mathrm{Ci}-$ ampa, 2014).

\section{Designing and Developing an Android RPG Game for Music Learning}

Based on the statement of the music teacher, we designed an Android RPG game for music learning, especially on Indonesia's traditional song. Our design based on "Permendikbud No. 24 Tahun 2016" and focused on music art learning in elementary school. This game called "Lagu Nusantara" because the student will play the main actor and adventure through every map. The player will find other people in the different village to learn a lot of Indonesia's traditional songs. Figure 1 shows the storyline of this game.

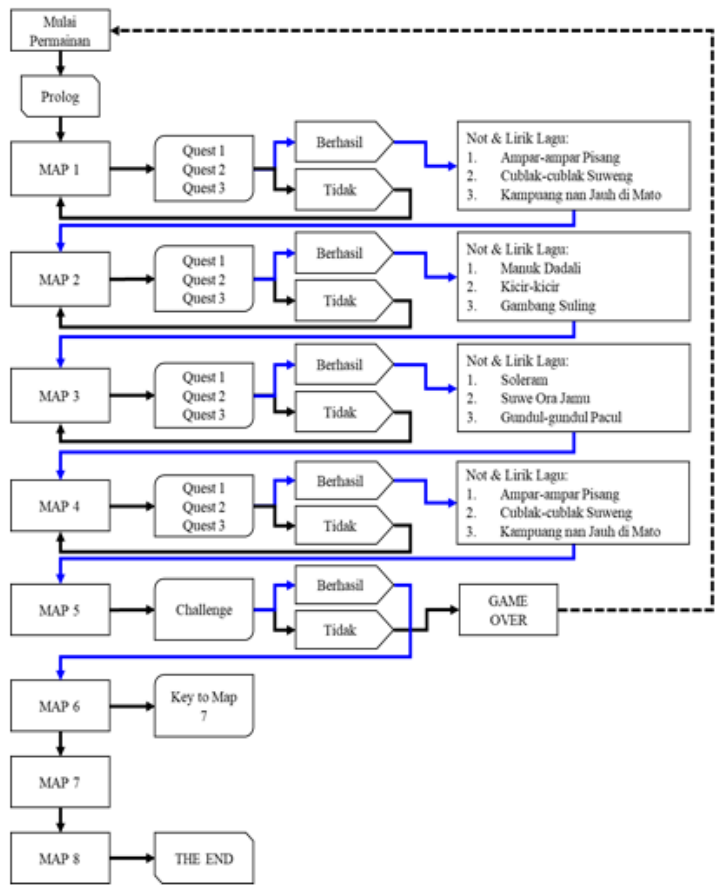

Figure 1. Flowchart of The Storyline

This game consists of several parts, such as a welcome screen, menu command, songs, actors, and map. Every part is connected by machine language which is included on RPG Maker MV software. Figure 2 shows the welcome screen of this game.

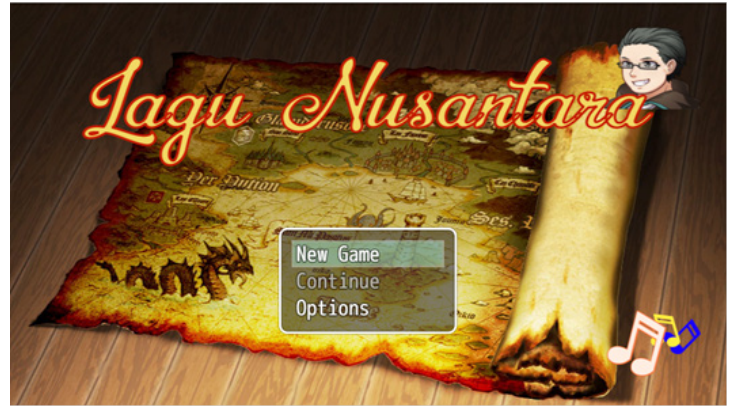

Figure 2. Welcome Screen

In Figure 2, there show three menus that will allow the player to do some command in this game. The new game command used for starting a new game. Continue command used for a beginning the game which has saved before. Options command used for open options menu such as setting up the music volume in this game. We also design actors in this game that shows in Table 1.

Table 1. Actors on Game

\begin{tabular}{cc}
\hline \multicolumn{2}{c}{ Main Actor } \\
\hline Figure & Name \\
\hline & \\
&
\end{tabular}

Secondary Actor

Figure Name

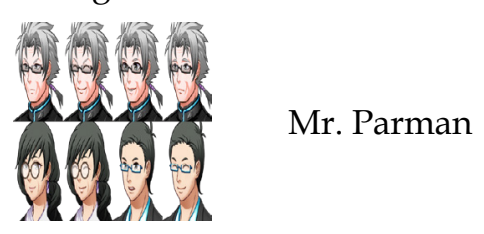

Non-Player Characters

Figure

Name

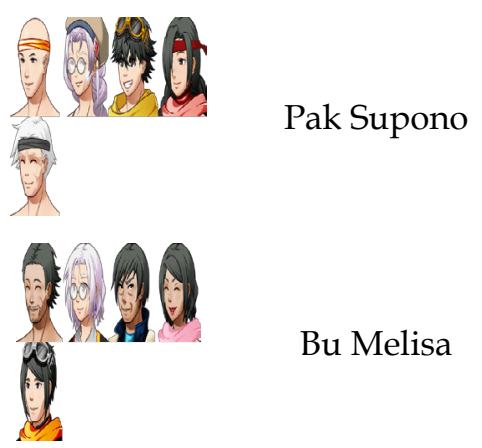




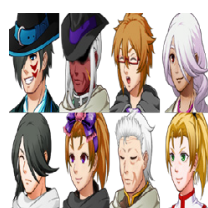

Didik
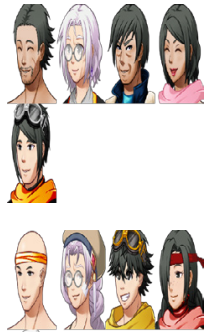

(7)
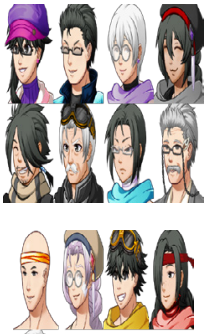

邹
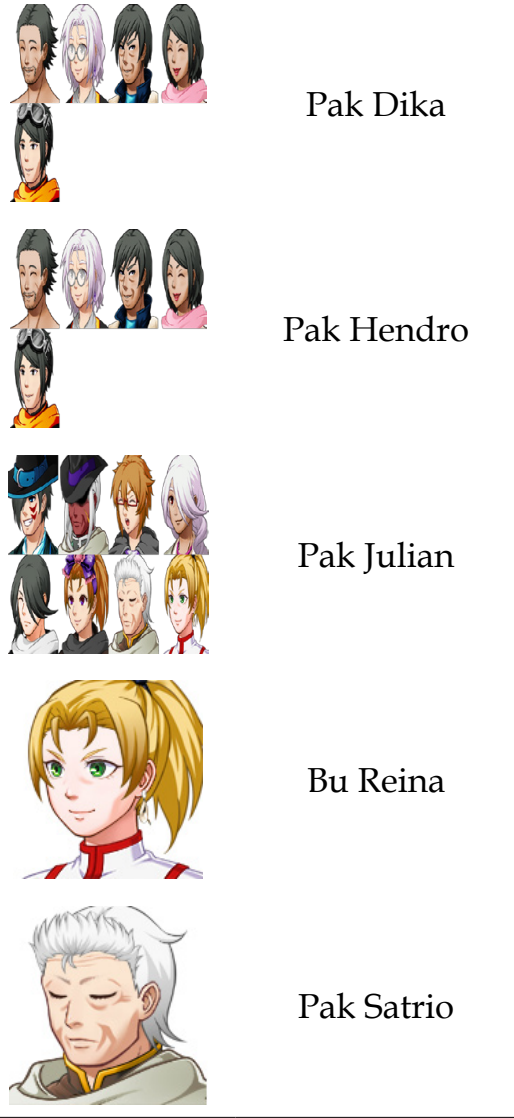

Pak Dika

Pak Hendro

Pak Julian
Inside this game, there is a map where the main actor learns about Indonesia's traditional songs. The main actor will read music score and sing together with NPC as a mission that actor have to finish. After the mission complete, the actor will receive a paper which is a lyric and music score as a reward. In this mission, the primary and secondary actor will earn some experience points that can increase an actor's base level. The example of the map shows in Figure 3 and Figure 4. Then, in Figure 5 and Figure 6 are the example of Android mobile deployment.

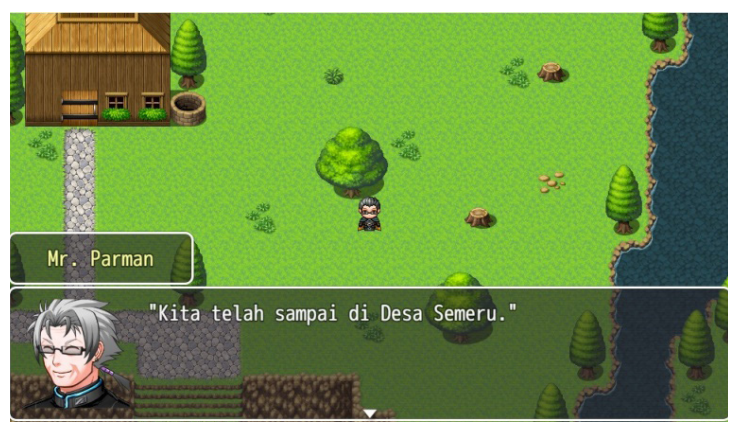

Figure 3. Example Map

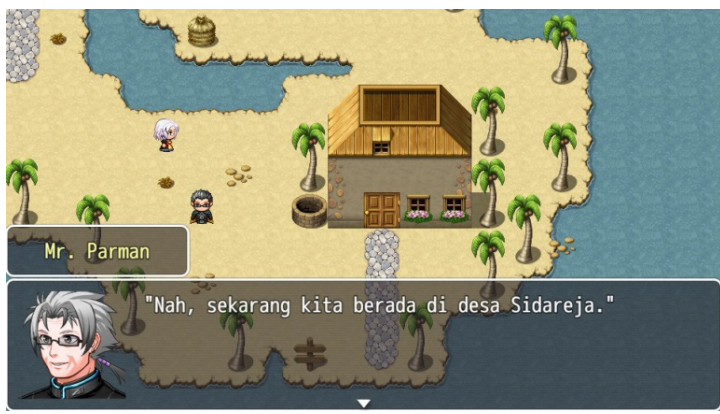

Figure 4. Example Map

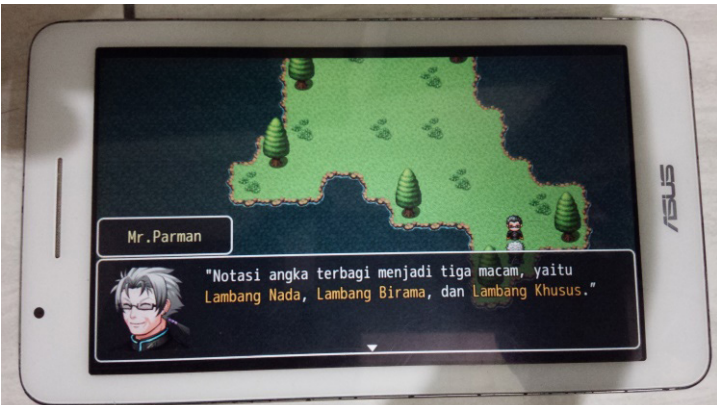

Figure 5. Deployment on Android Device 


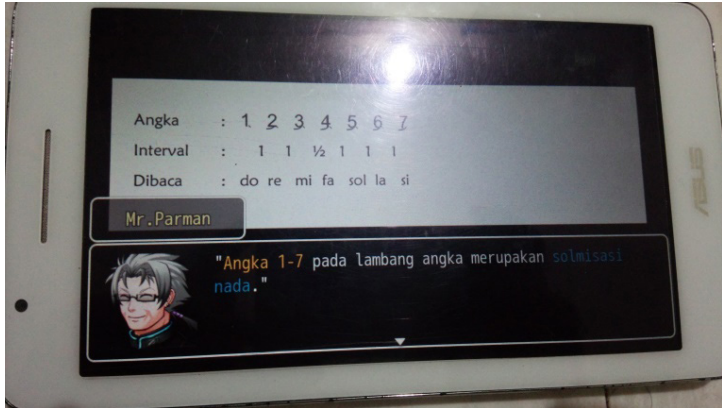

Figure 6. Deployment on Android Device

\section{Evaluation of Android RPG Game for Music Learning}

To test the worthiness of our product, we examined this game to the expert. We choose three expert judgment that consists of learning media expert, music art learning expert, and language expert. The media expert is Adriyanto Juliastomo Gundo, S.Si., M.Pd., lecturer of Faculty of Information Technology, Universitas Kristen Satya Wacana. The music art learning expert is Iwan Tri Yulianto, music teacher at Bethany Elementary School. The language expert is Dr. Sunardi, S.Pd., M.Pd., lecturer of Faculty of Teacher Training and Education, Universitas Kristen Satya Wacana.

From the learning media expert score, the Android RPG game that we designed obtained 3.6 for an average score. This score category is perfectly worthy for music learning based on conversion score (Purwanto, 2013). The music art learning expert gave a perfect score for this game. The average score is 4 . Then, from the language expert score, this game obtained 3.3 for an average score which score category is worthy. A detailed score of this product shows in Table 2.

From the learning media expert, there are some evaluation and suggestion for fixing our product. The expert evaluated that the music score and direction in this product is not clear enough. Some music score in this product is difficult to read because of the size. For information, our product is not optimized well for the small mobile device (less than 5-inch screen size). So, the user will have an extra attempt to read the music score. The expert suggests adding some information to this game such as instructions of use item or button inside the game. The expert found that some button somewhat confusing, especially the okay button. There is a no different button for okay command and the boat ride button, so the expert suggests to make a difference between this button. But overall, this game is excellent to use in the music learning process, especially for Indonesia's traditional song learning. Then, the part of product improvement shows in Figure 7.

In Figure 5, the controller button repaired. Controller button can hide the

Table 2. Test Score of Expert Judgement

\begin{tabular}{cccc}
\hline Kind of Test & Indicators & Score & Percentage \\
\hline $\begin{array}{c}\text { Learning Media Expert } \\
\text { Judgement Test }\end{array}$ & Display of visual communication & 3.7 & $92.5 \%$ \\
& Software utilization & 3.4 & $85 \%$ \\
Average Score & 3.6 & $90 \%$ \\
Music Art Learning & Rightness & 4 & $100 \%$ \\
Expert Judgement Test & Material coverage & 4 & $100 \%$ \\
& Novelty & 4 & $100 \%$ \\
Language Expert & Learning design & 4 & $100 \%$ \\
Judgement Test & Therage Score use of spelling, terms, and & 4 & $100 \%$ \\
& punctuation & 3.4 & $85 \%$ \\
& Average Score & 3.3 & $80 \%$ \\
\hline
\end{tabular}


main controller by touched it while the song played. We also change music score to the bigger one so that player can read clearly. Rule of thirds terms also fixed to arrange the better picture direction (Aswin \& Muttaqin, 2014).

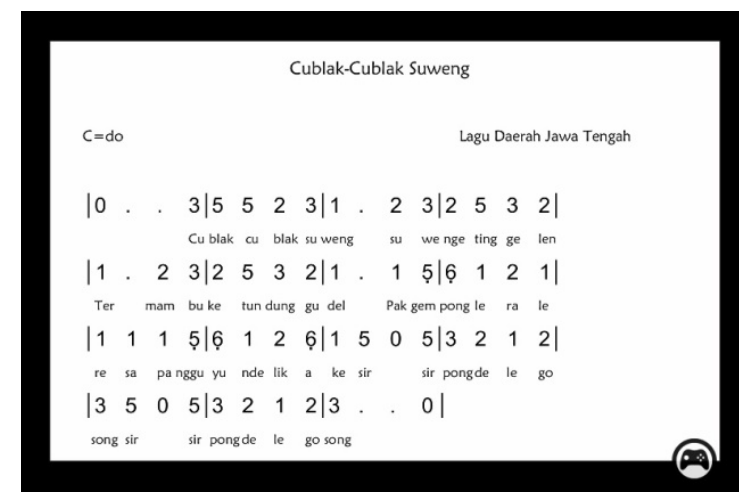

Figure 7. Product Improvement Based on Expert Evaluation

There are some evaluations and suggestions from the music art learning expert for this product. The music score needs improvement especially for the notes that shown in this game. The improvement focused on music notes with a slash. The expert noted that the explanations of slash in the music score must be clear and use the standard terms. In additions, the expert noted there should be clear instructions when the song played, for example adding gradations color like in karaoke lyrics to make it easier for the student to read the music notes. Moreover, adding metronome to the song instrument is a better choice to make it easier to learn. From the music art learning expert, this game got a perfect score because the expert assumed that this game is very educational and the innovation in the music art learning process. The product improvement based on expert evaluation and suggestion shows in Figure 8.

Based on language expert judgment, this game is good. There are some evaluations and suggestion for this product. The sentences which shown in this game should separate into two or three parts. The expert told that the sentences amount is too much. This condition will make the player feel bored. Use sentences in Bahasa should be shown as simple as possible but not decreasing the meaning. In addition, the dialogue text which displayed in the game should present well. The expert reminds about the term of the use of foreign words in Bahasa. Foreign words in this game must write in italic style. Capitalize, and regular words also must be different. There is no necessary improvement in dialogue part because the expert gives a high score in this part. Based on expert evaluations and suggestions, the product improvement shows in Figure 9.

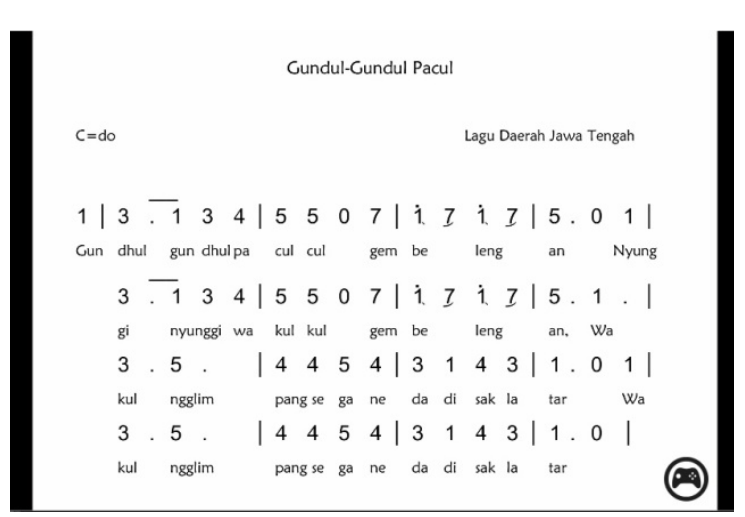

Figure 8. Product Improvement Based on Expert Evaluation

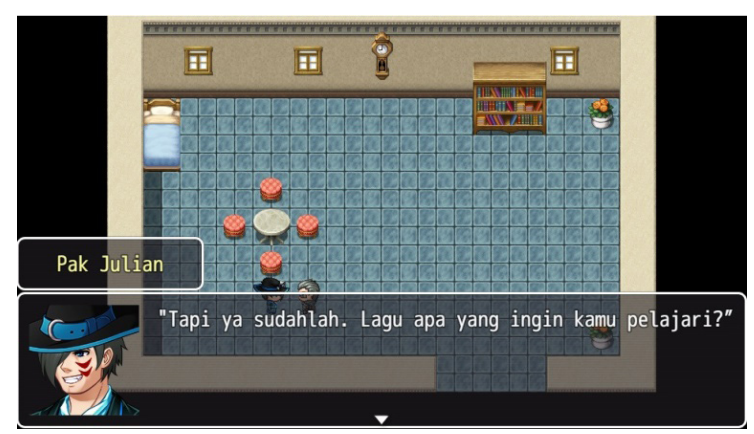

Figure 9. Product Improvement Based on Expert Evaluation

In Table 2, there is a score for this product based on expert judgment. In the media part, display of visual communication and software utilization got a score percentage above $80 \%$. Display of visual communication represents the attractiveness of learning media to attract student's attention. Color and image composition are essential things to make digital learning media eye-catching (Hendrawan et 
al., 2012; Adinoto, 2015; Febriyani \& Donna, 2016). Adding pictures, sound, and animation in this product can interest students to focus on the storyline of the game. This game which developed with adding conversation and built in the mobile devices also support the student to establish comprehensive reading skills (Kim \& Lee, 2016).

From the material coverage which shown in Table 2, this game presents the music art material very well. The perfect score that has given by expert is a proof. The material in this game consists of the basics of learning music score and how to learn Indonesia's traditional songs. The basics of learning music score include how to read the music notes and beats in music. This material is a primary material for elementary students before they learn about the complete music score. In the music learning process, the theory is an important thing to be mastered by the student (Amriyeni et al., 2013). This product displayed Indonesia's traditional music score from the biggest island of Indonesia as a representative form of the richness of Indonesia traditional songs. Adding songs from each of Indonesia's biggest island improve student's knowledge about songs from various provinces in Indonesia. This product is a kind of novelty in this technology era as a form of application of a useful model of art education (Utomo, 2016).

Based on expert judgment score, this game is worthy to use as learning media. Games that provided in the role-playing game genre is worthy to engage the learning process. The study before, told the same thing with this study which RPG game can use and increase student interest in the learning process (Erwin \& Florensa, 2013; Asriyatun \& Nugroho, 2014; Sari et al., 2014; Hartanto et al., 2016; Maharani et al., 2016; Ningsih et al., 2016; Hermawan et al., 2017) .

\section{CONCLUSION}

The lack of student interest and knowledge about Indonesia's traditional songs can make the existence of Indonesia's traditional song evicted. We know that today children generation prefers to listen to modern songs. So, music art learning process in the elementary school is urgently needed to remind and learn about Indonesia's traditional song. To promote student's interest in Indonesia's traditional song, we need something new and innovative. As an innovation, mobile learning media for music art learning is necessary based on student's habit who often play mobile games in their daily life. Music art learning media can build into RPG games that to attract student interest. Based on expert judgment validation's score, the music art learning media called "Lagu Nusantara" is worthy of supporting the student to learn about the basic of music learning and Indonesia's traditional songs. The average score is 3.6 for media representation, 4 for music learning material that presented, and 3.3 for the use of language. The worthiness of this media is above $90 \%$ (precisely $90.83 \%$ ). In conclusion, this RPG game can use by teacher or students to promote music art learning process, especially about Indonesia's traditional song.

\section{ACKNOWLEDGEMENTS}

We would like to thank everybody who helps this study, especially to Mr. Adriyanto Juliastomo Gundo, S.Si., M.Pd., Mr. Iwan Tri Yulianto, and Mr. Dr. Sunardi, S.Pd.

\section{REFERENCES}

Adinoto, A. P. D. (2014). Pembuatan Media Pembelajaran Interaktif tentang Pengolahan Sampah untuk Anak SD Kelas 1. Calyptra, 4(1), 1-7.

Alam, S. T., Nugroho, R. A., \& Budiman, I. (2014). Rancang Bangun Aplikasi Permainan (Games) Sebagai Media Pembelajaran Seni dan Budaya Banjar. Klik-Kumpulan Jurnal Ilmu Komputer, 1(1), 90-102.

Alfianto, Faruq, Totok Sumaryanto, F., \& Udi U. (2014). Pengembangan In- 
strumen Penilaian Apresiasi Seni Musik Materi Seni Budaya Sekolah Menengah Pertama. Innovative Journal of Curriculum and Educational Technology, 3(2), 44-52.

Amriyeni, Merisa, Idawati Syarif, \& Zona Iriani. (2013). Pengaruh Audio Visual Terhadap Hasil Belajar Siswa dalam Pembelajaran Tari Daerah Setempat Kelas X SMA Negeri 8 Padang. EJurnal Sendratasik, 2(1), 56-62.

Asriyatun, A., \& Nugroho, M. A. (2014). Pengembangan Game Edukatif Berbasis RPG Maker XP Sebagai Media Pembelajaran Akuntansi. Jurnal Pendidikan Akuntansi Indonesia, 12(1), 7992.

Aswin, M., Utomo T. P., \& Muttaqin, A. (2014). Penilaian Komposisi Rule of Thirds Pada Fotografi Menggunakan Bantuan Pengolahan Citra Digital. Jurnal Mahasiswa TEUB, 1(6), 1-5.

Bahari, Nooryan. (2008). Kritik Seni: Wacana Apresiasi dan Kreasi. Yogyakarta: Pustaka Pelajar.

Branch, R. M. (2009). Instructional Design: The ADDIE Approach. New York: Springer Science Business Media.

Chung, S. M., \& Wu, C. T. (2017). Designing Music Games and Mobile Apps for Early Music Learning. In Serious Games and Edutainment Applications (pp. 57-75). Springer International Publishing.

Ciampa, K. (2014). Learning In a Mobile Age: An Investigation of Student Motivation. Journal of Computer Assisted Learning, 30(1), 82-96.

Daryanto. (2013). Media Pembelajaran, Peranannya Sangat Penting Dalam Mencapai Tujuan Pembelajaran. Yogyakarta: Gave Media.

Desyandri. (2008). Rekonstruksi Mata Kuliah Pendidikan Seni SD 3 (Musik) Program Applied Approach (AA). Bahan Ajar. Padang: Universitas Negeri Padang.

Erwin, E., \& Florensa R. P. (2013). Game RPG" True Destiny" Menggunakan Aplikasi RPG Maker VX. Jurnal Teknik dan Ilmu Komputer, 2(8), 389-
401.

Febriani, Y., \& Donna, B. M. (2015). Media Animasi Pembelajaran Interaktif Siswa Kelas 1 SD. Jurnal EducatiO, 10(2), 280-297.

Fokides, E., \& Atsikpasi, P. (2016). Tablets in Education. Results from The Initiative ETiE, For Teaching Plants to Primary School Students. Education and Information Technologies, 1-19.

Furió, D., Juan, M. C., Seguí, I., \& Vivó, R. (2015). Mobile learning vs. Traditional Classroom Lessons: a Comparative Study. Journal of Computer Assisted Learning, 31(3), 189-201.

Hartanto, Novi., Arief Hidayat \& Fitro Nur H. (2016). Rancang Bangun Media Pembelajaran IPA Organ Pencernaan Berbasis Role Playing Game Untuk Kelas V SD. Komputaki, 1(1), 39-55.

Haßler, B., Major, L., \& Hennessy, S. (2016). Tablet Use in Schools: A Critical Review of the Evidence for Learning Outcomes. Journal of Computer Assisted Learning, 32(2), 139-156.

Hendrawan, H. S., Sunarto, M. D., \& Sutanto, T. (2012). Aplikasi Belajar Menulis Untuk Anak Prasekolah Berbasis Android. Jurnal JSIKA, 1(1).

Hermawan, D. P., Herumurti, D., \& Kuswardayan, I. (2017). Efektivitas Penggunaan Game Edukasi Berjenis puzzle, RPG dan Puzzle RPG Sebagai Sarana Belajar Matematika. JUTI: Jurnal Ilmiah Teknologi Informasi, 15(2), 195-205.

Hikam, A. R., Kariada, N., \& Santosa, K. (2013). Pengembangan Game Edukasi Visual Novel Berbasis Pembangunan Karakter Pada Materi Pelestarian Lingkungan. Journal of Biology Education, 2(2), 148-154.

Indrawan, Bagus., Totok S. F., \& Sunarto. (2016). Bentuk Komposisi dan Pesan Moral dalam Pertunjukan Musik Kiai Kanjeng. Catharsis: Journal of Arts Education, 5(2), 114-122.

Irawan, E., Soedarsono, R. M., \& Simatupang, G. L. L. (2014). Karakter Musikal Lagu Gedé Kepesindenan 
Karawitan Sunda. Resital: Jurnal Seni Pertunjukan, 15(1), 18-31.

Kim, S., \& Lee, Y. (2016). iStoryBook: An Interactive Media Supporting Dialogic Reading for Children's Reading Comprehension. International Journal of Multimedia and Ubiquitous Engineering, 11(11): 383-392.

Kusumadewi, Lidya F. \& S. Suharto. (2011). Peningkatan Hasil Belajar Seni Musik dengan Media Audio. Harmonia: Journal of Arts Research and Education, 10(2),

Maharani, S., Hatta, H. R., \& Selvyani, F. A. (2016). Game Sejarah Terbentuknya Kota Samarinda Menggunakan Role Playing Game (RPG) Maker VX Ace. Jurnal Infotel, 8(1), 56-63.

Mulyono, Untung. (2012). Pendikan Nilai Luhur Melalui Tembang (Lagu) Dolanan Anak. SELONDING: Jurnal Etnomusikologi, 1(1), 100-112.

Nadir, M. (2016). Urgensi Pembelajaran Berbasis Kearifan Lokal. Jurnal Pendidikan Agama Islam (Journal of Islamic Education Studies), 2(2), 299-330.

Ng, S. C., Lui, A. K., \& Kwok, A. C. (2015). Easy-to-Learn Piano: A Mobile Application for Learning Basic Music Theory and Piano Skill. In International Conference on Technology in Education (pp. 103-112). Springer Berlin Heidelberg.

Ningsih, N., Prabowo, P., \& Widodo, W. (2016). Pengembangan Media Pembelajaran Berbasis Role Playing Game (RPG) Maker XP Pada Materi Kesetimbangan Benda Tegar untuk Melatihkan Keterampilan Berpikir Kritis Siswa. JPPS: Jurnal Peneilitian Pendidikan Sains, 6(1), 1107-1112.

Perez, Darrin. (2016). Beginning RPG Maker $M V$. New York: Apress.

Purwanto, Ngalim. (2013). Prinsip-Prinsip dan Teknik Evaluasi Pengajaran. Bandung: Remaja Rosdakarya.

Raharja, Haryono, T., Soedarsono, R. M., \& Susanto, A. (2014). Pengaruh Sri Sultan Hamengku Buwono I pada Seni Karawitan Kraton Yogyakarta. Resital: Jurnal Seni Pertunjukan, 15(1), 43-
51.

Rahmawan, Eris F., Totok Sumaryanto, \& Supriyadi. (2016). Pengembangan Instrumen Penilaian Kinerja Kemampuan Bernyanyi Berbasis Android. Journal of Educational Research and Evaluation, 5(1), 81-89.

Rosmiati, A. (2014). TeknikStimulasi dalam Pendidikan Karakter Anak Usia Dini melalui Lirik Lagu Dolanan. Resital: Jurnal Seni Pertunjukan, 15(1), 71-82.

Sari, K. W., Saputro, S., \& Hastuti, B. (2014). Pengembangan Game Edukasi Kimia Berbasis Role Playing Game (RPG) Pada Materi Struktur Atom Sebagai Media Pembelajaran Mandiri Untuk Siswa Kelas X SMA Di Kabupaten Purworejo. Jurnal Pendidikan Kimia, 3(2), 96-104.

Septiana, Opta., Totok Sumaryanto, \& Agus Cahyono. (2016). Nilai Budaya Pertunjukkan Musik Terbangan Pada Masyarakat Semende. Catharsis: Journal of Arts Education, 5(2), 142-149.

Su, C. H., \& Cheng, C. H. (2015). A Mobile Gamification Learning System for Improving the Learning Motivation and Achievements. Journal of Computer Assisted Learning, 31(3), 268-286.

Sugiyono. (2015). Metode Penelitian Pendidikan Pendekatan Kuantitatif, Kualitatif, dan RED. Bandung: Alfabeta.

Suharto, Totok Sumaryanto, Victor Ganap, \& Santosa. (2017). Banyumasan Songs As Banyumas People's Character Reflection. Harmonia: Journal of Arts Research and Education, 17(1), 151-158.

Sukoyo, J. (2017). The Effectiveness of Javanese Songs In Cultivating Students' Characters. Jurnal Kependidikan: Penelitian Inovasi Pembelajaran, 1(2), 163173.

Sumirat, P. A. (2014). Aplikasi Alat Musik Gamelan Jawa Pada Perangkat Android. Jurnal Emitor, 14(1), 24-32.

Syaifudin, A. (2016). Apa itu Game RPG? Bahas Tuntas Pengertian RPG dan Contohnya. Retrieved from http:// www.gamebagus.net/2016/01/apa- 
itu-game-rpg-bahas-tuntas.html

Utomo, K. B. U. (2016). Model Manajemen Seni Yang Efektif. Prosiding. Seminar Nasional Pendidikan 2016. Surakatra, 2 April 2016.

Wagner, C. (2017). Digital Gamification in Private Music Education. Antistasis, 7(1): 115-121.

Wicaksono, Herwin Y. (2009). Kreativitas dalam Pembelajaran Musik. Cakrawala Pendiikan, 28(1), 1-12.
Wijayanto, B., G. R Lono L. Simatupang, \& Victor G. (2017). Strategi Musikal dalam Ritual Pujian dan Penyembahan Gereja Kristen Kharismatik. Resital: Jurnal Seni Pertunjukan, 16(3), 125140.

Yudarta, I. G., \& Pasek, I. N. (2017). Kecimol Music As Cultural Identification Of Sasak Ethnic. Mudra, 32(3), 314318. 